\title{
SANKSI HUKUM TERHADAP PIHAK PENANGGUNG ATAS KLAIM ASURANSI YANG TIDAK DIPENUHI PENANGGUNG BERDASARKAN HUKUM POSITIF
}

\author{
Rani Apriani \\ Fakultas Hukum Universitas Singaperbangsa Karawang \\ rani88_fhunsika@yahoo.com \\ DOI: https://doi.org/10.29313/sh.v16i1.5130
}

\begin{abstract}
ABSTRAK
Tidak selamanya praktek asuransi berjalan dengan baik. Dalam praktek ditemukan ditolaknya klaim asuransi tertanggung oleh penanggung setelah risiko, kerugian atau peristiwa yang tidak diinginkan terjadi. Tulisan ini bertujuan untuk mengetahui perlindungan hukum bagi tertanggung yang menghadapi penolakan klaim asuransi dan mengetahui akibat hukum apabila pihak penanggung menolak klaim dari pihak tertanggung. Metode penelitian menggunakan pendekatan yuridis normatif dengan menggunakan teknik analisis data secara kualitatif. Hasil penelitian menunjukkan Perlindungan hukum bagi pihak tertanggung atas penolakan klaim telah ada lembaga khusus yang berwenang melakukan pengaturan, pengawasan, pemeriksaan, dan penyidikan di bidang asuransi. Pihak tertanggung dapat melakukan pengaduan atas penolakan klaim yang terjadi kepada OJK dan dibantu oleh OJK. OJK telah mengeluarkan POJK No: 1/POJK.07/2013 tentang Perlindungan Konsumen Sektor Jasa Keuangan yang secara khusus dibuat untuk melindungi konsumen yang merasa dirugikan oleh perusahaan asuransi. Apabila penolakan asuransi atas kelalaian pihak asuransi maka sanksi hukumnya berupa peringatan tertulis, pembatasan kegiatan usaha, dan pencabutan izin usaha sebagaimana yang terdapat dalam pasal 77 ayat (1) POJK No 69/Pojk.05/2016 tentang Penyelenggaraan Usaha Perusahaan Asuransi, Perusahaan Asuransi Syariah, Perusahaan Reasuransi, dan Perusahaan Reasuransi Syariah, sedangkan apabila penolakan asuransi atas kelalaian pihak tertanggung maka akibat hukumnya perusahaan asuransi dapat melakukan penuntutan pihak tertanggung tersebut.
\end{abstract}

Kata Kunci: Klaim Asuransi, Sanksi Hukum, Otoritas Jasa Keuangan.

\section{ABSTRACT}

Not always insurance practices go well. In practice it is found that insurance claims are insured by the insurer after the risk, loss or unwanted event occurs. This paper aims to find out about legal protection for the insured who faces rejection of insurance claims and knows the legal consequences if the insurer rejects the claim from the insured party. The research method uses a normative juridical approach using qualitative data analysis techniques. The results of the study show that legal protection for the insured party for rejecting claims has a special institution authorized to regulate, supervise, inspect and investigate insurance. The insured party can make a complaint 
over the rejection of the claim that occurred to the OJK and assisted by the OJK. OJK has issued POJK No: 1/ POJK.07/ 2013 concerning Consumer Protection of the Financial Services Sector specifically designed to protect consumers who feel disadvantaged by insurance companies. If the insurance refusal is due to the negligence of the insurance party, then the legal sanctions will be in the form of written warnings, restrictions on business activities, and revocation of business licenses as contained in article 77 paragraph (1) POJK No. 69/ Pojk., Reinsurance Company, and Sharia Reinsurance Company, whereas if the insurance refuses the negligence of the insured party, the legal consequence is that the insurance company can prosecute the insured party.

Keywords: Insurance Claims, Legal Sanctions, Financial Services Authority.

\section{A. PENDAHULUAN}

\section{Latar Belakang Masalah}

Dalam siklus kehidupan yang dimulai sejak lahir sampai meninggal dunia, baik jasmani maupun rohani seseorang tidak terlepas dari risiko yang mungkin akan terjadi, seperti risiko manusia untuk jatuh sakit. Seseorang yang menderita sakit harus menanggung biaya perawatan baik biaya rawat inap di rumah sakit maupun biaya transportasi serta obat-obatan yang harus dibeli sehingga ada ungkapan bahwa sehat itu mahal harganya. Untuk membantu meringankan beban biaya yang ditanggung oleh orang yang sakit ataupun keluarga dari orang yang sakit tersebut maka perlu adanya pihak lain yang dapat menanggung risiko tersebut. Pengalihan risiko ini bertujuan untuk memikul kerugian yang mana disebabkan karena suatu kejadian tertentu. Kerugian tersebut dapat dialihkan kepada pihak lain yang bergerak di bidang penerimaan risiko yaitu perusahaan asuransi. Jadi perihal risiko dapat dialihkan atau dapat ditanggung oleh perusahaan asuransi tersebut dengan ketentuan dan juga syarat yang telah ditentukan sebelumnya.

Perusahaan asuransi sebagai perusahaan jasa, pada satu sisi menjual jasa kepada pelanggan, sedangkan pada sisi lain, perusahaan asuransi adalah sebagai investor dari tabungan masyarakat kepada investasi yang produktif. ${ }^{1}$ Asuransi atau pertanggungan yang tujuannya adalah semata-mata untuk mengganti kerugian tertanggung, maka nilai dari kerugian yang dipertanggungkan itu penting untuk diketahui. Maksudnya ialah,

${ }^{1}$ Sri Redjeki Hartono, Hukum Asuransi dan Perusahaan Asuransi, Jakarta, Sinar Grafika, 1999, hlm. 3 
biaya asuransi tersebut harus adil menurut besar kecilnya risiko yang dipertanggungkan. ${ }^{2}$

Ketentuan asuransi telah dijelaskan dalam Undang-Undang Nomor 40 Tahun 2014 tentang Perasuransian. Dalam Pasal 1 Angka 1 Undang-Undang Nomor 40 Tahun 2014 tentang Perasuransian menjelaskan bahwa para pihak yang berkaitan dengan asuransi atau pertanggungan minimal terdapat dua yaitu penanggung dan tertanggung. Penanggung merupakan pihak yang berhak menerima pembayaran uang pertanggungan dan memberi penggantian kepada tertanggung apabila terjadi kerugian. Tertanggung merupakan pihak yang mengadakan perjanjian asuransi dengan membayar sejumlah uang kepada penanggung dan menerima uang penggantian atas kerugian yang diderita.

Pembuatan perjanjian asuransi harus memenuhi syarat-syarat perjanjian dimana ketentuan-ketentuan yang mengatur hal ini terdapat pada Pasal 1320 Kitab Undang Undang Hukum Perdata (selanjutnya disebut KUH Perdata) mengenai syarat sahnya perjanjian. Penanggung dan tertanggung yang mengikatkan diri dalam perjanjian asuransi harus sesuai dengan ketentuan peraturan perundang-undangan yang berlaku yakni terdapat dalam Pasal 1338 KUH Perdata. Ketentuan ini menyatakan bahwa ketika perjanjian telah disepakati kedua belah pihak, maka perjanjian tersebut akan berlaku sebagai undang-undang yang akan mengikat pihak-pihak di dalamnya.

Proses pengalihan risiko dari tertanggung kepada penanggung tidak terjadi begitu saja tanpa kewajiban apa-apa. Tertanggung yang telah sepakat akan mengadakan perjanjian asuransi dengan penanggung yang dalam hal ini adalah asuransi kesehatan, mempunyai kewajiban membayar sejumlah uang kepada penanggung. Pembayaran uang tersebut digunakan untuk mengganti kerugian yang dialami tertanggung sedangkan penanggung wajib untuk menanggung besaran kerugian tersebut. Namun apabila kemudian peristiwa yang dimaksudkan dalam perjanjian tidak terjadi maka uang tersebut tetap menjadi milik pihak yang menanggung. ${ }^{3}$

\footnotetext{
2 Abbas Salim, Dasar - Dasar Asuransi, Jakarta, Raja Grafindo Persada, 1995, hlm. 12.

3. Djoko Prakoso dan I Ketut Murtika, Hukum Asuransi Indonesia, Jakarta, Bina Aksara, 1989, hlm. 1
} 
Ketentuan-ketentuan yang dipakai oleh penanggung dalam mengikatkan dirinya dengan tertanggung diterjemahkan dalam polis. Polis ini nantinya akan menjadi tanda bukti adanya perjanjian asuransi. Tertanggung harus membaca polis dengan seksama, bukan hanya membaca saja melainkan perlu memahami isi polis tersebut. Misalnya kondisi apa saja yang termasuk dalam pertanggungan asuransi, bagaimana cara pengajuan klaim asuransi, dan lain sebagainya. Disini penanggung sangat berperan penting untuk menjelaskan semua isi polis kepada tertanggung. Hal ini merupakan kewajiban penanggung, apabila penanggung keberatan menjelaskan polis, tertanggung harus lebih teliti dengan melakukan pengecekan terhadap polis.

Kedua belah pihak harus memberikan keterangan secara jujur. Keteranganketerangan yang tidak disampaikan dengan jujur, benar dan jelas baik itu dari penanggung maupun tertanggung akan menimbulkan masalah pada saat pengajuan klaim. Pengajuan klaim akan dilakukan tertanggung apabila ia mengalami peristiwa yang telah diperjanjikan dalam polis misalnya jatuh sakit. Ketentuan mengenai prosedur dan persyaratan pengajuan klaim tidak diatur baik dalam undang-undang maupun dalam peraturan pelaksananya, melainkan telah ditentukan dalam polis asuransi yang dibuat perusahaan asuransi. Tertanggung yang dapat memenuhi prosedur pengajuan klaim asuransi dengan benar, maka pengajuan klaimnya akan diterima oleh penanggung serta membayar klaim sesuai dengan isi polis. Namun demikian tidak selamanya praktek asuransi berjalan dengan baik. Pada kenyataannya banyak kasus-kasus yang terjadi di dalam masyarakat, dimana kasus yang sering terjadi adalah ditolaknya klaim asuransi tertanggung oleh penanggung setelah risiko, kerugian atau peristiwa yang tidak diinginkan terjadi. Baik dikarenakan adanya pelanggaran dalam perjanjian asuransi yang telah disepakati atau adanya itikad buruk dari tertanggung atau penanggung.

Berdasarkan penjelasan diatas dapat ditarik sebuah kenyataan bahwa saat ini dalam pengajuan klaim asuransi sendiri masih memiliki permasalahan yang membutuhkan solusi sehingga dapat berjalan adil baik terhadap pihak tertanggung maupun pihak penanggung.

\section{Identifikasi Masalah}

Artikel ini akan membahas Bagaimana perlindungan hukum bagi tertanggung atas penolakan klaim asuransi dari penanggung menurut hukum positif, dan Bagaimana 
sanksi hukum apabila pihak penanggung menolak klaim asuransi dari pihak tertanggung Berdasarkan Hukum Positif.

\section{Metode Penelitian}

Metode penelitian dalam penulisan ini menggunakan pendekatan yuridis normatif karena penulis melakukan inventarisasi peraturan perundangundangan yang mengatur masalah asuransi. Spesifikasi penelitian menggunakan deskriptif analitis dengan menggambarkan suatu kenyataan dan fakta-fakta yang berkaitan dengan hukum perasuransian. Teknik analisis data menggunakan metode kualitatif karena tidak menggunakan rumus dan angka..

\section{B. PEMBAHASAN}

\section{a. Perlindungan Hukum bagi Tertanggung Atas Penolakan Klaim Asuransi dari Penanggung Menurut Hukum Positif}

Perkembangan ekonomi di Indonesia berkembang sangat cepat, serta "makin kompleks dan bervariasinya produk jasa keuangan, munculnya gejala konglomerasi perusahaan jasa keuangan, dan globalisasi industri jasa keuangan". 4 Sampailah akhirnya dibentuk suatu lembaga pengawasan khusus pada sektor keuangan yang independen yang kedudukannya di luar pemerintah yakni Otoritas Jasa Keuangan.

Otoritas Jasa Keuangan bergerak di bawah landasan yuridis Undang-Undang Nomor 21 Tahun 2011 tentang Otoritas Jasa Keuangan. OJK, yaitu: “Lembaga yang independen dan bebas dari campur tangan pihak lain, yang mempunyai fungsi, tugas, dan wewenang pengaturan, pengawasan, pemeriksaan, dan penyidikan sebagaimana dimaksud dalam Undang-Undang ini". Seluruh kegiatan yang berkaitan dengan lembaga jasa keuangan terintegrasi dengan Otoritas Jasa Keuangan, maka seluruh pengaturan dan pengawasan dilakukan oleh Otoritas Jasa

\footnotetext{
${ }^{4}$ Adrian Sutedi, Aspek Hukum Otoritas Jasa Keuangan, Jakarta, Raih Asa Sukses, 2014, hlm. 38.

${ }^{5}$ Pasal 1 angka 1 Undang-Undang Nomor 21 Tahun 2011 tentang Otoritas Jasa Keuangan.
} 
Keuangan. OJK berfungsi menyelenggarakan sistem pengaturan dan pengawasan yang terintegrasi terhadap keseluruhan kegiatan di dalam sektor jasa keuangan. ${ }^{6}$

Pemberian perlindungan terhadap konsumen yang dirugikan pelaku usaha oleh OJK merupakan bukti terintegrasinya pengawasan, pengaturan, dan perlindungan konsumen lembaga jasa keuangan. Salah satu tujuan dari pembentukan Otoritas Jasa Keuangan yaitu mampu melindungi kepentingan konsumen dan masyarakat, maka OJK diberikan kewenangan untuk memberikan perlindungan terhadap hak konsumen pada sektor keuangan. Dalam melakukan perlindungan konsumen dan masyarakat, maka Otoritas Jasa Keuangan diberikan beberapa kewenangan untuk melakukan tindakan-tindakan guna membantu mencegah kerugian terhadap konsumen dan masyarakat. Salah satu kewenangan yang diberikan oleh undang-undang kepada Otoritas Jasa Keuangan mengenai perlindungan konsumen yang bersifat preventif.

Sejalan dengan hal tersebut, Otoritas Jasa Keuangan diberikan pula kewenangan oleh undang-undang untuk melakukan pembelaan hukum bagi konsumen dan masyarakat, sebagaimana Pasal 30 huruf a Undang-Undang Nomor 21 Tahun 2011 tentang Otoritas Jasa Keuangan, “memerintahkan atau melakukan tindakan tertentu kepada lembaga jasa keuangan untuk menyelesaikan pengaduan konsumen yang dirugikan lembaga jasa keuangan dimaksud". ${ }^{7}$ Perlindungan konsumen yang dilakukan oleh Otoritas Jasa Keuangan meliputi konsumen pada sektor jasa keuangan, sebagaimana yang dijelaskan dalam Pasal 1 angka 3 POJK Nomor 1/POJK.07/2013 tentang Perlindungan Konsumen Sektor Jasa Keuangan, "Perlindungan Konsumen adalah perlindungan terhadap Konsumen dengan cakupan perilaku Pelaku Usaha Jasa Keuangan". ${ }^{8}$

Berhubungan dengan hal tersebut, maka Otoritas Jasa Keuangan sebagai lembaga yang diberikan kewenangan untuk melindungi konsumen pada sektor jasa keuangan khususnya pada sektor asuransi, memiliki tugas untuk membantu memperjuangkan konsumen dalam mendapatkan haknya yakni pembayaran uang

\footnotetext{
6. Pasal 5 Undang-Undang Nomor 21 Tahun 2011 tentang Otoritas Jasa Keuangan

${ }^{7}$ Pasal 30 huruf a Undang-Undang Nomor 21 Tahun 2011 tentang Otoritas Jasa Keuangan.

${ }^{8}$ Pasal 1 angka 3 Peraturan Otoritas Jasa Keuangan Nomor 1/POJK.07/2013 tentang Perlindungan Konsumen Sektor Jasa Keuangan
} 
pertanggungan, selain itu untuk tercapainya suatu kesejahteraan, kebahagiaan serta keadilan bagi masyarakat yang merupakan amanah dari Pancasila, dan "untuk meningkatkan kepercayaan masyarakat terhadap kinerja Otoritas Jasa Keuangan". 9

Dalam POJK Nomor: 1/POJK.07/2013 tentang Perlindungan Konsumen Sektor Jasa Keuangan juga telah diatur mengenai perlindungan hukum bagi tertanggung yang menghadapi penolakan klaim asuransi, yaitu yang mengatur mengenai kewajiban pelaku usaha jasa keuangan yaitu Perusahaan Asuransi untuk menyampaikan informasi kepada tertanggung mengenai penerimaan, penundaan atau penolakan permohonan klaim asuransi dan wajib menyampaikan alasan penerimaan, penundaan ataupun penolakan tersebut sehingga pihak tertanggung pun tau alasannya mengapa klaimnya itu ditolak, dan dapat memperbaiki kembali syaratsyarat yang belum terpenuhi sebagaimana yang terdapat dalam Pasal 6 ayat (1) dan ayat (2) POJK Nomor 1/POJK.07/2013 tentang Perlindungan Konsumen Sektor Jasa Keuangan. Untuk mencegah terjadinya kesalahpahaman mengenai segala aturan yang dikeluarkan oleh Perusahaan Asuransi dan untuk memudahkan tertanggung tersebut memahami aturan yang ada, maka dalam setiap dokumen terutama dalam polis asuransi, Perusahaan Asuransi wajib menggunakan istilah, frasa atau kalimat yang sederhana Bahasa Indonesia yang mudah dimengerti oleh Konsumen dalam setiap dokumen. Dalam hal melindungi tertanggung maka harus dijelaskan pula mengenai hak dan kewajiban tertanggung di dalam bisnis asuransi agar tertanggung tau apa saja yang menjadi hak dan yang menjadi kewajibannya.

Sengketa dalam asuransi terutama sengketa penolakan klaim asuransi ini sudah banyak terjadi. Salah satu penyebab sengketa penolakan klaim asuransi adalah perubahan aturan ataupun persyaratan yang dilakukan secara sepihak oleh perusahaan asuransi tanpa pemberitahuan ataupun persetujuan dari pihak tertanggungnya.

Perusahaan Asuransi dalam membuat perjanjian juga harus adil, misalnya dalam hal tertanggung telah sepakat untuk membayar premi kepada Perusahaan

\footnotetext{
${ }^{9} 9$ Adrian Sutedi, Op. Cit, hlm. 97
} 
Asuransi, maka Perusahaan Asuransi juga harus memberikan ganti kerugian sesuai dengan perjanjian yang telah tertera di dalam polis, hal ini diatur juga dalam POJK Nomor 1/POJK.07/2013 tentang Perlindungan Konsumen Sektor Jasa Keuangan Pasal 21, yaitu "Pelaku Usaha Jasa Keuangan wajib memenuhi keseimbangan, keadilan, dan kewajaran dalam pembuatan perjanjian dengan Konsumen". ${ }^{10}$ Seperti yang diketahui, pada masa sekarang ini banyak Perusahaan Asuransi yang menggunakan perjanjian baku dengan alasan untuk menghemat waktu dan agar prosesnya lebih cepat, tetapi dengan dipakainya perjanjian baku dalam hal asuransi, bukan berarti pihak tertanggung harus tunduk pada semua peraturan baru, tambahan ataupun terhadap perubahan yang dibuat secara sepihak oleh Perusahaan Asuransi.

Pihak tertanggung yang dirugikan oleh Perusahaan Asuransi dapat terlebih dahulu melakukan pengaduan kepada perusahaan asuransi tersebut agar masalahnya segera diselesaikan. Dalam Pasal 32 POJK Nomor 1/POJK.07/2013 tentang Perlindungan Konsumen Sektor Jasa Keuangan menyebutkan bahwa "Pelaku Usaha Jasa Keuangan wajib memiliki dan melaksanakan mekanisme pelayanan dan penyelesaian pengaduan bagi Konsumen." ${ }^{11}$ Dalam hal perlindungan hukum terhadap tertanggung ini Otoritas Jasa Keuangan juga melakukan pengawasan kepatuhan pelaku usaha jasa keuangan terhadap penerapan ketentuan perlindungan konsumen dan pengawasan tersebut dilaksanakan baik secara langsung maupun tidak langsung.

Perlindungan hukum bagi tertanggung yang menghadapi penolakan klaim asuransi memang penting sekali karena klaim yang diajukan oleh pemegang polis asuransi terhadap Perusahaan Asuransi tidak jarang berbelit-belit, dan ditolak dengan berbagai alasan. Sejak penandatangan perjanjian asuransi sudah tercantum unsur perjanjian baku atau kontrak baku yang berpotensi merugikan, dan ditambah dengan pelaksanaan isi perjanjian asuransi termasuk tentang klaim asuransi yang juga berbelit- belit dan cenderung dipersukar, maka kedudukan tertanggung menjadi lebih lemah dan tidak berdaya. Maka dari itu perlindungan hukum lebih

${ }^{10}$ Pasal 21 POJK Nomor 1/POJK.07/2013 tentang Perlindungan Konsumen Sektor Jasa Keuangan. ${ }^{11}$ Pasal 32 POJK Nomor 1/POJK.07/2013 tentang Perlindungan Konsumen Sektor Jasa Keuangan. 
menempatkan kedudukan tertanggung sebagai pemegang polis sebagai pihak yang lebih diberikan perhatian oleh ketentuan peraturan perundang-undangan dibandingkan dengan Perusahaan Asuransi.

Penanganan klaim dan keluhan dalam asuransi oleh Perusahaan Asuransi sebenarnya wajib ditangani dengan proses yang cepat, adil, tidak boleh berbelit belit, apalagi sampai mempersulit tertanggung. Perusahaan Asuransi juga tidak boleh memperlambat pembayaran klaim, Perusahaan Asuransi, Perusahaan Asuransi Syariah, perusahaan reasuransi, dan perusahaan reasuransi syariah dilarang melakukan tindakan yang dapat memperlambat penyelesaian atau pembayaran klaim, atau tidak melakukan tindakan yang seharusnya dilakukan sehingga mengakibatkan kelambatan penyelesaian atau pembayaran klaim." 12

Perusahaan Asuransi harus telah membayar klaim paling lama 30 (tiga puluh) hari sejak adanya kesepakatan antara tertanggung dan penanggung atau kepastian mengenai jumlah klaim yang harus dibayar sebagaimana terdapat dalam Pasal 27 Keputusan Menteri Keuangan Nomor 422/KMK.06/2003 tentang Penyelenggaraan Usaha Perusahaan Asuransi dan Perusahaan Reasuransi. Jadi Perusahaan Asuransi wajib segera membayar klaim asuransi yang diajukan oleh tertanggung apabila tertanggung sudah memenuhi semua syarat yang telah tertera dalam polis.

Perlindungan hukum terhadap nasabah asuransi atau pemegang polis tidak diatur secara khusus dalam KUHPerdata. Namun demikian berdasarkan Pasal 1

KUHDagang, ketentuan umum perjanjian dalam KUHPerdata dapat berlaku bagi perjanjian asuransi. Terdapat beberapa pasal yang terkait dan dapat berlaku bagi perjanjian asuransi serta memberikan perlindungan bagi pemegang polis. Keterkaitan perlindungan hukum bagi pemegang polis dengan KUHPerdata dijelaskan dalam beberapa pasal. $^{13}$

\footnotetext{
12 Pasal 31 ayat (2) Undang-Undang Nomor 40 Tahun 2014 tentang Perasuransian.

${ }^{13}$ Sastrawidjaja, Man Suparman, Aspek-Aspek Hukum Asuransi dan Surat Berharga, Bandung, Alumni, 1997, hlm. 9-15.
} 
Mengacu kepada pendapat para ahli hukum tentang pengertian asuransi, maka dapat disimpulkan bahwa asuransi juga termasuk ke dalam perjanjian yaitu perjanjian asuransi. Dalam Pasal 1320 KUHPerdata yang mengatur tentang syarat sahnya perjanjian, maka adanya ketentuan ini memberikan konsekuensi bahwa pemegang polis yang berpendapat jika terjadinya perjanjian asuransi karena adanya kesesatan (dwaling), paksaan (dwang) dan penipuan (bedrog) dari penanggung dapat mengajukan permohonan pembatalan perjanjian asuransi ke pengadilan. Apabila perjanjian asuransi tersebut dinyatakan batal baik seluruhnya maupun sebagian dan tertanggung atau pemegang polis beritikad baik, maka tertanggung berhak untuk menuntut pengembalian premi yang telah dibayarkan.

Asuransi adalah perjanjian timbal balik, ${ }^{14}$ artinya dalam perjanjian asuransi kedua belah pihak memiliki kewajiban yang harus dilakukan, baik dari pihak tertanggung untuk membayarkan sejumlah uang dalam bentuk premi maupun dari pihak penanggung untuk mengganti kerugian yang dialami oleh tertanggung akibat peristiwa yang tidak pasti. Pasal 1266 KUHPerdata, mengatur bahwa syarat batal dianggap selalu dicantumkan dalam perjanjian timbal balik apabila salah satu pihak tidak memenuhi kewajibannya. Bagi pemegang polis, hal ini perlu diperhatikan sebab kemungkinan yang bersangkutan terlambat dalam melakukan pembayaran premi. Namun hal ini tidak menyebabkan perjanjian batal dengan sendirinya, akan tetapi harus dimintakan pembatalan kepada hakim. Dalam praktik biasanya dicantumkan dalam polis klausula yang menentukan bahwa perjanjian asuransi tidak akan berjalan apabila premi tidak dibayar pada waktunya. Hal ini untuk menghindari agar setiap terjadi keterlambatan pembayaran premi tidak perlu minta pembatalan kepada pengadilan karena dianggap kurang praktis.

Dalam perjanjian asuransi, yaitu jika penanggung yang memiliki kewajiban memberikan ganti kerugian atau sejumlah uang terhadap tertanggung ternyata melakukan ingkar janji, maka pemegang polis dapat menuntut penggantian biaya, ganti rugi, dan bunga yang diatur dalam Pasal 1267 KUHPerdata. Pada perjanjian asuransi, prestasi penanggung digantungkan pada peristiwa yang belum

${ }^{14}$ Sentosa Sembiring, Op.Cit, hlm. 17. 
pasti terjadi. Untuk menghindari penanggung menambah syarat-syarat lainnya dalam memberikan ganti rugi atau sejumlah uang, pemegang polis harus memperhatikan ketentuan Pasal 1253 KUHPerdata sampai dengan Pasal 1262 KUHPerdata.

Apabila Perusahaan Asuransi melakukan perbuatan melanggar hukum, yang membawa kerugian kepada tertanggung maka tertanggung dapat menuntut penanggung bila dapat membuktikan bahwa penanggung telah melakukan perbuatan yang merugikan tersebut. Begitu pun apabila pihak tertanggung yang melakukan perbuatan yang melanggar hukum yang menimbulkan kerugian kepada pihak penanggung, maka tertanggung tersebut dapat dituntut oleh pihak penanggung. Perlindungan hukum terhadap nasabah asuransi sebagai pihak tertanggung, dalam hal ini tertanggung berada dalam posisi sebagai konsumen yang menerima jasa pelayanan dari pihak asuransi yang telah memberikan jaminan terhadap segala kemungkinan peristiwa yang akan terjadi pada diri tertanggung. Walaupun undangundang tersebut berjudul UU Perlindungan Konsumen, namun ketentuan di dalamnya lebih banyak mengatur tentang perilaku pelaku usaha. Hal ini dapat dipahami, karena kerugian yang diderita oleh konsumen seringkali akibat dari pelaku usaha, sehingga perilaku pelaku usaha ini perlu diatur dan bagi para pelanggar dikenakan sanksi yang setimpal. Esensi dari undang-undang ini adalah mengatur perilaku pelaku usaha dengan tujuan agar konsumen terlindungi secara hukum. ${ }^{15}$

Pengertian tentang perlindungan konsumen diartikan cukup luas, yaitu dalam Pasal 1 angka (1) Undang-Undang Nomor 8 Tahun 1999 tentang Perlindungan Konsumen, yang berbunyi: "Segala upaya yang menjamin adanya kepastian hukum untuk memberikan perlindungan hukum kepada konsumen."16 Perlindungan hukum terhadap tertanggung merupakan penerapan dari berbagai hal yang berkaitan dengan kewajiban-kewajiban dan hak-hak yang dimiliki oleh masing-masing pihak yaitu pihak tertanggung (nasabah) dan pihak penanggung (perusahaan asuransi).

\footnotetext{
${ }^{15}$ Neni Sri Imaniyati, Perlindungan Konsumen Dalam Hubungannya Dengan Perlindungan Hukum Terhadap Nasabah, Jurnal Hukum Bisnis Volume 30 No 1, 2011, hlm.48-57.

${ }^{16}$ Pasal 1 angka 1 Undang-Undang Nomor 8 Tahun 1999 tentang Perlindungan Konsumen.
} 
Jika dihubungkan dengan perjanjian asuransi, maka hak pemegang polis atau tertanggung sebagai konsumen dalam Pasal 4 Undang-Undang Nomor 8 Tahun 1999 tentang Perlindungan Konsumen dapat dijadikan acuan, yaitu:

a. Hak untuk memilih jenis asuransi yang ditawarkan;

b. Hak atas informasi yang benar, jelas dan jujur mengenai manfaat dan jaminan asuransi;

c. Hak untuk didengar pendapat dan keluhannya atas jasa dan pelayanan petugas asuransi;

d. Hak untuk mendapatkan advokasi, perlindungan, dan upaya penyelesaian sengketa perlindungan konsumen jika terjadi sengketa;

e. Hak untuk diperlakukan atau dilayani secara benar dan jujur serta tidak diskriminatif;

f. Hak untuk mendapatkan kompensasi, ganti rugi dan/atau penggantian, jasa yang diterima tidak sesuai dengan perjanjian atau tidak sebagaimana mestinya.

Kewajiban tertanggung sebagai konsumen dapat mengacu pada Pasal 5 Undang-Undang Nomor 8 Tahun 1999 tentang Perlindungan Konsumen, yaitu:

a. Membaca atau mengikuti petunjuk informasi dan prosedur yang ditetapkan oleh perusahaan asuransi;

b. Beritikad baik dalam melakukan transaksi atau menutup perjanjian asuransi;

c. Membayar sesuai dengan nilai tukar yang disepakati;

d. Mengikuti upaya penyelesaian hukum sengketa perlindungan konsumen secara patut.

Hak Perusahaan Asuransi sebagai pelaku usaha dapat mengacu pada Pasal 6 Undang-Undang Nomor 8 Tahun 1999 tentang Perlindungan Konsumen, yaitu:

a. Hak menerima pembayaran premi yang sesuai dengan kesepakatan;

b. Hak untuk mendapatkan perlindungan hukum dari tindakan konsumen atau tertanggung yang beritikad tidak baik;

c. Hak untuk melakukan pembelaan diri sepatutnya di dalam penyelesaian hukum sengketa konsumen; 
d. Hak untuk merehabilitasi nama baik apabila tidak terbukti secara hukum bahwa kerugian konsumen tidak diakibatkan oleh jasa yang diperdagangkan;

e. Hak-hak yang diatur dalam ketentuan peraturan perundang-undangan lainnya.

Kewajiban Perusahaan Asuransi sebagai pelaku usaha mengacu pada Pasal 7 Undang-Undang Nomor 8 Tahun 1999 tentang Perlindungan Konsumen, yaitu:

a. Beritikad baik dalam melakukan kegiatan usahanya;

b. Memberikan informasi yang benar, jelas, dan jujur mengenai manfaat dan jaminan dari asuransi yang ditawarkan;

c. Memperlakukan dan melayani konsumen dengan jujur dan tidak diskriminatif;

d. Memberikan kompensasi, ganti rugi, atau penggantian atas kerugian yang diderita konsumen.

Undang-undang tentang Perlindungan Konsumen tidak hanya mencantumkan hak-hak dan kewajiban-kewajiban dari konsumen, melainkan juga hak-hak dan kewajiban-kewajiban dari pelaku usaha. Namun, terlihat bahwa hak yang diberikan kepada konsumen Pasal 4 Undang-Undang Nomor 8 Tahun 1999 tentang Perlindungan Konsumen lebih banyak dibandingkan dengan hak pelaku usaha Pasal 6 Undang- Undang Nomor 8 Tahun 1999 tentang Perlindungan Konsumen dan kewajiban pelaku usaha pada Pasal 7 Undang-Undang Nomor 8 Tahun 1999 tentang Perlindungan Konsumen lebih banyak dari kewajiban konsumen Pasal 5 Undang-Undang Nomor 8 Tahun 1999 tentang Perlindungan Konsumen. UU Perlindungan Konsumen selain mengatur hak dan kewajiban pelaku usaha, juga mengatur perbuatan yang dilarang dilakukan oleh pelaku usaha yang dapat menjadi acuan bagi Perusahaan Asuransi, antara lain:

a. Memperdagangkan jasa asuransi yang tidak sesuai dengan standar yang dipersyaratkan dan ketentuan peraturan perundang-undangan, yaitu yang tidak sesuai dengan yang diatur dalam KUHPerdata, KUHDagang, UU Perasuransian; 
b. Memperdagangkan jasa asuransi yang tidak sesuai dengan janji yang dinyatakan dalam keterangan, iklan dan promosi;

c. Menawarkan, mempromosikan, mengiklankan asuransi yang tidak benar;

d. Menawarkan, mempromosikan, mengiklankan asuransi yang menyesatkan;

e. Menawarkan jasa asuransi dengan cara pemaksaan atau cara lain yang dapat menimbulkan gangguan baik fisik maupun psikis terhadap konsumen;

f. Memproduksi iklan yang mengelabui konsumen.

Undang-Undang Perlindungan Konsumen juga mengatur tanggungjawab pelaku usaha pada Pasal 19 Undang-Undang Nomor 8 Tahun 1999 tentang Perlindungan Konsumen. Dengan mengacu pada ketentuan Pasal 19 UndangUndang Nomor 8 Tahun 1999 tentang Perlindungan Konsumen ini maka Perusahaan Asuransi bertanggungjawab memberikan ganti rugi atas kerugian yang diderita pemegang polis. Namun hal ini tidak berlaku apabila Perusahaan Asuransi dapat membuktikan bahwa kerugian yang diderita oleh pemegang polis merupakan kesalahan dari pemegang polis itu sendiri.

Pasal 23 Undang-Undang Nomor 8 Tahun 1999 tentang Perlindungan Konsumen merupakan salah satu pasal yang tampaknya diselipkan secara spesifik, khusus mengatur hak konsumen untuk menggugat pelaku usaha yang menolak, dan/atau tidak memberi tanggapan, dan/atau tidak memenuhi ganti rugi atas tuntutan konsumen sebagaimana dimaksud dalam Pasal 19 UndangUndang Nomor 8 Tahun 1999 tentang Perlindungan Konsumen, baik melalui Lembaga Alternatif Penyelesaian Sengketa yaitu Badan Mediasi Asuransi Indonesia yang telah terdaftar di OJK, maupun dengan mengajukannya ke badan peradilan di tempat kedudukan konsumen baik ke Pengadilan Negeri ataupun ke Pengadilan Niaga untuk menyelesaikan sengketa klaim asuransi yang terjadi. 
Selain diatur dalam Undang-Undang Perlindungan Konsumen, segala hal yang berkaitan dengan hak-hak nasabah juga diatur dalam KUHDagang, antara lain: ${ }^{17}$

a. Pasal 259 KUHDagang, menuntut agar polis ditandatangani oleh penanggung;

b. Pasal 260 KUHDagang, menuntut agar polis segera disahkan oleh penanggung;

c. Pasal 261 KUHDagang, meminta ganti kerugian kepada penanggung apabila lalai menandatangani dan menyerahkan polis, sehingga menimbulkan kerugian bagi tertanggung;

d. Pasal 272 KUHDagang, melalui pengadilan, tertanggung dapat membebaskan penanggung dari segala kewajibannya pada waktu yang akan datang, untuk selanjutnya tertanggung dapat mengasuransikan kepentingannya kepada penanggung lain untuk waktu dan bahaya yang sama dengan asuransi yang pertama;

e. Pasal 280 KUHDagang, tertanggung memiliki hak dan ketegasan dalam memilih serta mendapatkan ganti kerugian dari salah satu penanggung saja;

f. Pasal 281 KUHDagang, menuntut pengembalian premi baik seluruhnya ataupun sebagian, apabila perjanjian asuransi batal atau gugur. Hak tertanggung terkait hal ini dilakukan apabila tertanggung beritikad baik, sedangkan penanggung bersangkutan belum menanggung risiko.

Aturan dalam KUHDagang juga dapat digunakan untuk memberikan perlindungan terhadap pemegang polis. Untuk mencegah supaya perjanjian asuransi tidak menjadi perjudian atau pertaruhan, maka dalam Pasal 254 KUHDagang diatur mengenai pelarangan para pihak dalam perjanjian, baik pada waktu diadakannya perjanjian maupun selama berlangsungnya perjanjian asuransi menyatakan melepaskan hal-hal yang oleh ketentuan undang-undang diharuskan.

\footnotetext{
${ }^{17}$ Man Suparman dan Endang, Hukum Asuransi: Perlindungan Tertanggung Asuransi Deposito Usaha perasuransian, Bandung, Alumni, 1997, hlm. 17 - 20.
} 
Jika melihat ketentuan Pasal 255 KUHDagang, seolah-olah polis merupakan syarat mutlak untuk terbentuknya perjanjian asuransi. Namun bila memperhatikan Pasal

257 KUHDagang ternyata tidak benar. Dalam pasal ini disebutkan bahwa dalam perjanjian asuransi diterbitkan seketika setelah ditutup, hak dan kewajiban timbal balik dari tertanggung dan penanggung mulai berlaku sejak saat itu. Artinya apabila kedua belah pihak telah menutup perjanjian asuransi akan tetapi polisnya belum dibuat, maka tertanggung tetap berhak menuntut ganti rugi apabila peristiwa yang diperjanjikan terjadi. Tertanggung harus membuktikan bahwa perjanjian asuransi telah ditutup disertai alat bukti yang ada, misalnya surat menyurat antara penanggung dengan tertanggung, catatan penanggung, nota penutupan, dll.

KUHDagang juga mengatur tentang asuransi yang ditutup melalui perantaraan makelar atau agen. Dari Pasal 260 KUHDagang diketahui bahwa jika perjanjian asuransi ditutup dengan perantaraan makelar, maka polis yang telah ditandatangani harus diserahkan dalam waktu delapan hari sejak ditandatangani. Sedangkan dalam Pasal 261 KUHDagang menjelaskan bahwa jika terjadi kelalaian dalam hal yang ditetapkan dalam Pasal 259 KUHDagang dan Pasal 260 KUHDagang, maka penanggung wajib memberikan ganti rugi. Berkaitan dengan hal ini, apabila terdapat kesalahan broker atau agen asuransi dalam memberikan pelayanan kepada tertanggung, maka broker asuransi dapat dituntut baik secara perdata maupun pidana.

Aturan dalam KUHDagang juga dapat digunakan untuk memberikan perlindungan terhadap pemegang polis. Untuk mencegah supaya perjanjian asuransi tidak menjadi perjudian atau pertaruhan, maka dalam Pasal 254 KUHDagang diatur mengenai pelarangan para pihak dalam perjanjian, baik pada waktu diadakannya perjanjian maupun selama berlangsungnya perjanjian asuransi menyatakan melepaskan hal-hal yang oleh ketentuan undang-undang diharuskan.

Jika melihat ketentuan Pasal 255 KUHDagang, seolah-olah polis merupakan syarat mutlak untuk terbentuknya perjanjian asuransi. Namun bila memperhatikan Pasal 
257 KUHDagang ternyata tidak benar. Dalam pasal ini disebutkan bahwa dalam perjanjian asuransi diterbitkan seketika setelah ditutup, hak dan kewajiban timbal balik dari tertanggung dan penanggung mulai berlaku sejak saat itu. Artinya apabila kedua belah pihak telah menutup perjanjian asuransi akan tetapi polisnya belum dibuat, maka tertanggung tetap berhak menuntut ganti rugi apabila peristiwa yang diperjanjikan terjadi. Tertanggung harus membuktikan bahwa perjanjian asuransi telah ditutup disertai alat bukti yang ada, misalnya surat menyurat antara penanggung dengan tertanggung, catatan penanggung, nota penutupan, dll.

KUHDagang juga mengatur tentang asuransi yang ditutup melalui perantaraan makelar atau agen. Dari Pasal 260 KUHDagang diketahui bahwa jika perjanjian asuransi ditutup dengan perantaraan makelar, maka polis yang telah ditandatangani harus diserahkan dalam waktu delapan hari sejak ditandatangani. Sedangkan dalam Pasal 261 KUHDagang menjelaskan bahwa jika terjadi kelalaian dalam hal yang ditetapkan dalam Pasal 259 KUHDagang dan Pasal 260 KUHDagang, maka penanggung wajib memberikan ganti rugi. Berkaitan dengan hal ini, apabila terdapat kesalahan broker atau agen asuransi dalam memberikan pelayanan kepada tertanggung, maka broker asuransi dapat dituntut baik secara perdata maupun pidana.

\section{b. Sanksi Hukum Pihak Penanggung Atas Penolakan Klaim Asuransi Dari Pihak Tertanggung Berdasarkan Hukum Positif}

Menunjuk pada Pasal 37 Peraturan Otoritas Jasa Keuangan (POJK) Nomor 69/POJK.05/2016 tentang Penyelenggaraan Usaha Perusahaan Asuransi, Perusahaan Asuransi Syariah, Perusahaan Reasuransi, dan Perusahaan Reasuransi Syariah, yang berisi:

"Perusahaan atau Unit Syariah dilarang melakukan tindakan yang dapat memperlambat penyelesaian atau pembayaran klaim, atau tidak melakukan tindakan yang seharusnya dilakukan sehingga mengakibatkan keterlambatan penyelesaian atau pembayaran klaim."18

\footnotetext{
${ }^{18}$ Pasal 37 POJK Nomor 69/POJK.05/2016 tentang Penyelenggaraan Usaha Perusahaan
} Asuransi, Perusahaan Asuransi Syariah, Perusahaan Reasuransi, dan Perusahaan Reasuransi Syariah 
Sesuai dengan aturan tersebut maka Perusahaan Asuransi wajib melakukan penyelesaian klaim. Apabila hal tersebut dilanggar, Perusahaan Asuransi dapat dikenakan sanksi sesuai Pasal 77 ayat (1) POJK Nomor 69/POJK.05/2016 tentang Penyelenggaraan Usaha Perusahaan Asuransi, Perusahaan Asuransi Syariah, Perusahaan Reasuransi, dan Perusahaan Reasuransi Syariah yaitu:

Peraturan OJK ini dikenai sanksi administratif berupa:
a. Peringatan tertulis;
b. Pembatasan kegiatan usaha, untuk sebagian atau seluruh kegiatan usaha; dan
c. Pencabutan izin usaha." 19

Pada Pasal 77 ayat (4) POJK Nomor 69/POJK.05/2016 tentang Penyelenggaraan Usaha Perusahaan Asuransi, Perusahaan Asuransi Syariah, Perusahaan Reasuransi, dan Perusahaan Reasuransi Syariah juga menyebutkan bahwa:

"Selain sanksi administratif sebagaimana dimaksud pada ayat (1) dan ayat (2), OJK dapat menambahkan sanksi tambahan berupa:

a. Larangan untuk memasarkan produk asuransi atau produk asuransi syariah untuk lini usaha tertentu; dan/atau

b. Larangan menjadi pemegang saham, pengendali, direksi, dewan komisaris, atau yang setara dengan pemegang saham, pengendali, direksi, dan dewan komisaris, atau menduduki jabatan eksekutif di bawah direksi, atau yang setara dengan jabatan eksekutif di bawah direksi, pada perusahaan perasuransian." 20

Untuk prosedur dan tata cara pengenaan sanksi administratif bagi Perusahaan Asuransi sendiri dilakukan secara bertahap yang diawali dengan sanksi administratif berupa peringatan tertulis. Pengenaan sanksi administratif berupa peringatan tertulis dilakukan paling banyak 3 (tiga) kali berturut-turut atas setiap pelanggaran. Jangka waktu pemberlakuan sanksi administratif berupa peringatan tertulis bagi Perusahaan Asuransi masing-masing paling lama 30 (tiga puluh) hari sejak ditetapkannya sanksi administratif tersebut.

\footnotetext{
${ }^{19}$ Pasal 77 ayat (1) POJK Nomor 69/POJK.05/2016 tentang Penyelenggaraan Usaha Perusahaan Asuransi, Perusahaan Asuransi Syariah, Perusahaan Reasuransi, dan Perusahaan Reasuransi Syariah.

20 Pasal 77 ayat (4) POJK Nomor 69/POJK.05/2016 Tentang Penyelenggaraan Usaha Perusahaan Asuransi, Perusahaan Asuransi Syariah, Perusahaan Reasuransi, dan Perusahaan Reasuransi Syariah 
Perusahaan Asuransi akan dikenai sanksi administratif berupa pembatasan kegiatan usaha apabila Perusahaan Asuransi tersebut tidak dapat mengatasi pelanggaran yang merupakan penyebab terbitnya sanksi peringatan tertulis terakhir sampai dengan jangka waktu yang sudah ditentukan. Untuk pembatasan kegiatan usaha ini bisa untuk sebagian ataupun seluruh kegiatan usaha. Apabila dengan dikenakannya sanksi pembatasan kegiatan usaha untuk seluruh kegiatan usaha tetapi Perusahaan Asuransi masih tidak dapat mengatasi pelanggaran yang ada barulah sanksi terbe rat yang akan dikenakan yaitu pencabutan izin usaha Perusahaan Asuransi tersebut. Aturan ini sesuai dengan Pasal 6 POJK Nomor 17/POJK.05/2017 tentang Prosedur dan Tata Cara Pengenaan Sanksi Administratif di Bidang Perasuransian dan Pemblokiran Kekayaan Perusahaan Asuransi, Perusahaan Asuransi Syariah, Perusahaan Reasuransi, dan Perusahaan Reasuransi Syariah.

Kejahatan dalam asuransi bisa juga dilakukan oleh pihak tertanggung. Banyak tertanggung yang mengikuti asuransi itu untuk mencari keuntungan semata, bahkan hal tersebut dijadikan sebagai salah satu pekerjaan untuk mencari nafkah, dan banyak rumah sakit atau dokter yang dengan mudahnya menyuruh seorang pasien untuk dirawat inap padahal penyakit yang diderita pasien tersebut merupakan penyakit ringan dan tidak parah yang tidak memerlukan pasien tersebut untuk dirawat. Hal ini lah yang memberikan peluang terhadap para tertanggung yang nakal untuk mencari keuntungan dalam asuransi.

OJK sebagai lembaga pengawas keuangan di Indonesia pun meminta kepada setiap perusahaan asuransi agar menuntut setiap tertanggung nakal yang mencurigakan dan diduga klaim asuransinya mengandung unsur yang tidak sesuai dengan fakta dan/atau tidak dapat terverifikasi kebenarannya misalnya dituntut dengan Pasal 378 KUHPidana tentang Penipuan.

\section{PENUTUP}

Perlindungan hukum bagi pihak tertanggung yang menghadapi penolakan klaim untuk saat ini telah ada lembaga khusus yang berwenang melakukan pengaturan, pengawasan, pemeriksaan, dan penyidikan di bidang asuransi. Pihak tertanggung 
tersebut dapat melakukan pengaduan atas penolakan klaim yang terjadi kepada OJK. Kasus tersebut akan dibantu penyelesaiannya oleh OJK. Untuk melindungi tertanggung yang menghadapi penolakan klaim asuransi maka OJK telah mengeluarkan peraturan yaitu Peraturan Otoritas Jasa Keuangan (POJK) Nomor: 1/POJK.07/2013 tentang Perlindungan Konsumen Sektor Jasa Keuangan yang secara khusus dibuat untuk melindungi para konsumen termasuk juga tertanggung yang merasa dirugikan oleh perusahaan asuransi. Selain diatur dalam undang-undang tersebut, perlindungan hukum untuk tertanggung juga telah diatur dalam Undang- Undang Nomor 40 Tahun 2014 tentang Perasuransian, KUHPerdata, Undang- Undang Nomor 8 Tahun 1999 tentang Perlindungan Konsumen, dan bahkan KUHD.

Penolakan klaim asuransi atas kelalaian pihak asuransi maka sanksi hukumnya diberikan sanksi oleh OJK sebagai otoritas yang berwenang berupa peringatan tertulis, pembatasan kegiatan usaha, dan pencabutan izin usaha sebagaimana yang terdapat dalam pasal 77 ayat (1) POJK Nomor 69/Pojk.05/2016 tentang Penyelenggaraan Usaha Perusahaan Asuransi, Perusahaan Asuransi Syariah, Perusahaan Reasuransi, dan Perusahaan Reasuransi Syariah, sedangkan apabila penolakan asuransi atas kelalaian pihak tertanggung maka sanksi hukumnya perusahaan asuransi dapat melakukan penuntutan pihak tertanggung tersebut.

Keadaan ini menunjukkan kasus sengketa klaim yang terjadi biasanya karena pihak penanggung yaitu perusahaan asuransi tidak menjelaskan secara detail dan rinci apa saja yang menjadi syarat dan aturan-aturan mengenai pengajuan klaim, dan pihak tertanggung pun tidak membaca dengan teliti terlebih dahulu polis asuransinya, oleh karena itu, untuk melindungi tertanggung, maka OJK harusnya lebih mengawasi lagi pelaksanaan kewajiban perusahaan asuransi untuk menjelaskan secara detail dan rinci apa saja yang terdapat di dalam polis sehingga nantinya tidak menimbulkan kesalahpahaman antara tertanggung dan Perusahaan Asuransi dan dapat menghindari adanya sengketa.

OJK sebaiknya memberikan sanksi yang tegas terhadap perusahaan asuransi yang melakukan pelanggaran seperti menghambat penyelesaian atau pembayaran klaim agar memberikan efek jera sehingga perusahaan asuransi tersebut tidak 
mengulangi perbuatannya dan menjadi peringatan bagi perusahaan asuransi yang lain. 


\section{DAFTAR ISI}

\section{A. Buku}

Abbas Salim, Dasar - Dasar Asuransi, Jakarta, Raja Grafindo Persada, 1995.

Adrian Sutedi, Aspek Hukum Otoritas Jasa Keuangan, Jakarta, Raih Asa Sukses, 2014.

Djoko Prakoso dan I Ketut Murtika, Hukum Asuransi Indonesia, Jakarta, Bina Aksara, 1989.

Man Suparman dan Endang, Hukum Asuransi: Perlindungan Tertanggung Asuransi Deposito Usaha perasuransian, Bandung, Alumni, 1997.

Neni Sri Imaniyati, Perlindungan Konsumen Dalam Hubungannya Dengan Perlindungan Hukum Terhadap Nasabah, Jurnal Hukum Bisnis Volume 30 No. 1, 2011.

Man Suparman Sastrawidjaja, Aspek-Aspek Hukum Asuransi dan Surat Berharga, Bandung, Alumni.

Sri Redjeki Hartono, Hukum Asuransi dan Perusahaan Asuransi, Jakarta, Sinar Grafika, 1999,

\section{B. Jurnal/Makalah}

Agus Wahyudi, Filsafat Politik Barat dan Masalah Keadilan, Jurnal Filsafat No 1 April 2004.

Ismansyah, Aparatur Hukum Sebagai Salah Satu Penyebab Lemahnya Penegakan Hukum di Indonesia, Jurnal Hukum Pidana dan Kriminologi, Vol XII Januari 2014.

Muladi, Pengadilan Pidana Bagi Pelanggar HAM Berat di Era Reformasi, Jurnal Demokrasi, Jakarta, 2002.

\section{Peraturan Perundang-undangan}

Undang-Undang Dasar 1945

Kitab undang-undang Hukum Perdata (KUHPerdata)

Undang-Undang No.8 Tahun 1999 Tentang Perlindungan Konsumen UndangUndang Nomor 21 Tahun 2011 tentang Otoritas Jasa Keuangan UndangUndang Nomor 40 Tahun 2014 tentang Perasuransian.

Peraturan Otoritas Jasa Keuangan Nomor 1/POJK.07/2013 tentangn Perlindungan Konsumen Sektor Jasa Keuangan.

POJK Nomor 69/POJK.05/2016 tentang Penyelenggaraan Usaha Perusahaan Asuransi, Perusahaan Asuransi Syariah, Perusahaan Reasuransi, dan Perusahaan Reasuransi Syariah 